\title{
STRATEGIC APPROACH TO QUALITY MANAGEMENT OF THE CULTURAL AND NATURAL HERITAGE
}

\author{
STRATEŠKI PRISTUP UPRAVLJANJU \\ KVALITETOM KULTURNE I PRIRODNE BAŠTINE \\ Izv. prof. dr. sc. Violeta Šugar \\ Sveučilište Jurja Dobrile u Puli, \\ Fakultet ekonomije i turizma „Dr. Mijo Mirković““ \\ Pula, Hrvatska/Croatia \\ E-mail: vsugar@unipu.hr \\ Dr. sc. Tatiana Zanini Gavranić \\ Arena Hospitality Group, Pula, Hrvatska/Croatia \\ E-mail: tzanini@arenahospitalitygroup.com
}

UDK/UDC: 005.6+7.025.1:008:338.48

JEL klasifikacija/JEL classification: L15; Z32

DOI: 10.30657/hdmk.2020.26

Pregledni članak/Review

Jezik/Language: Hrvatski/Croatian

\begin{abstract}
The paper researches and compares the quality management systems (QMS) of the natural and cultural heritage sites in Clroatia, European Union (EU) and worldwide. This paper is the result of a theoretical study carried out as a follow up of a previous research on integrated quality management of tourist destinations, quality standards and quality measurement. There is a lack of sources on this subject, as well as on implementation of a culture of quality, which is generally attributed to the scarcity of economic resources. There is no unanimity in the perception of the need of quality management of the cultural heritage, which is even sometimes perceived as excessive additional burden. But since the cultural heritage sites are undoubtedly a tourist attraction and a valuable income source there should be awareness of the need for quality management and quality measurement. The research started with the following hypothesis: by implementing the Balanced Scorecard (BSC) the heritage sites could improve their QMS and empower the systematic monitoring of realisation of their strategic and operational goals. The practical implications of the presented strategic management model could help preventing the situation of endangering, altering, even destroying some valuable sites, such as Pula, Dubrovnik or Plitvice Lakes in Croatia or Murujuga in Western Australia, Taj Mahal in India, cultural sites in Syria, Iraq and many other.
\end{abstract}

Key words: quality management, strategy, heritage sites, balanced scorecard.

\section{INTRODUCTION}


How to keep the appreciation of heritage and contemporary cultural expression at the heart of tourism for generations to come, is one of the current key topics of the World Tourism Organisation (UNWTO). "When managed responsibly cultural tourism can enrich the lives of both travellers and residents, promoting diversity and intercultural dialogue. The Kyoto Declaration will help us to ensure that our world's rich heritage and diverse creativity are wonders that our children too will have the chance to discover for themselves". ${ }^{1}$ Tourism destination as a unit is an extremely complex business system, whose management, and strategic planning must take into consideration a variety of factors, such as sustainable development (ecological, cultural, social and economic sustainability), local population and tourists. Globalised society also imposes new standards of market behaviour and competition. The common denominator, the starting point and goal is quality. UNWTO quality in tourism derives from the satisfaction of consumers with the services provided, i.e. their compliance with requirements and expectations, and the relationship between price and value (value for money). There is no single, generally accepted definition of quality, many authors agree that concept, perception and understanding of quality appear to be rather subjective. Various concepts of quality in tourism (as well as of quality in general) consist of the following: quality as excellence, quality as zero defects, quality as fitness for purpose, reduction of variations, service to meet the needs, requirements and/or expectations. Therefore, the main point is that quality starts with the customer and ends with customer's satisfaction, which can be defined as the customer's fulfilment response. ${ }^{2}$ In the last two decades cultural tourism as a form and niche market of tourism has received considerable attention. Richards ${ }^{3}$ established that heritage tourism was a major new area of tourism demand and that governments were eager to develop this market that could be used to boost local culture and aid the seasonable and geographic spread of tourism. In Germany, cultural tourism was regarded as a mega-trend and experts expected considerable international growth in this area ${ }^{4}$. Alvarez and Korzay ${ }^{5}$ point out that focusing on cultural and heritage tourism is an important tourism development strategy. ICOMOS $^{6}$ defined heritage as a broad concept that includes the natural as well as the cultural environment. It encompasses landscapes, historic places, sites and built environments, as well as biodiversity, collections, past and continuing cultural practices, knowledge and living experiences. According to the Global Code of Ethics for Tourism (GCET) ${ }^{7}$ tourism is a user of the cultural heritage of mankind and contributor to its enhancement. But also there are numerous heritage sites worldwide endangered by the economic activities and operations (i.e. mining), such as Murujuga in Australia ${ }^{8}$, destroyed due to the war (i.e. Mostar Old bridge, Bosnia and Herzegovina, Buddha statues in Afghanistan), or endangered by the mass tourism

\footnotetext{
1 The UNWTO Executive Director Manuel Butler at the Fourth World Conference on Culture and Tourism, https://www.unwto.org/preserving-cultural-identities-for-the-future-of-tourism (19. 12. 2019)

2 Violeta Šugar, EU $i$ odabir modela upravljanja kvalitetom hrvatskih turističkih desttinacija, doctoral dissertation, 2008.

${ }^{3}$ Greg Richards, "Tourism attraction systems: Exploring cultural behaviour", Annals of Tourism Research, 29, 2002.

${ }^{4}$ Andrea Hausmann, "Cultural tourism: Marketing challenges and opportunities for German cultural heritage", International Journal of Heritage Studies, Vol. 13, No. 2, 2007.

${ }^{5}$ Maria D. Alvarez and Meral Korzay, "Turkey as a heritage tourism destination: The role of knowledge", Journal of Hospitality Marketing and Management, 20, 2011.

${ }^{6}$ The International Council of Monuments and Sites (ICOMOS), https://www.icomos.org/en/2016-11-10-13-5313/icomos-and-the-world-heritage-convention-4 (15.12.2019)

${ }^{7}$ Global Code of Ethics for Tourism (GCET), https://www.unwto.org/global-code-of-ethics-for-tourism (20. 12. 2019)

${ }^{8}$ Maurizio Quagliuolo, "Quality Management at World Heritage Sites: Challenges", Quality Management of Cultural Heritage: Problems and Best Practices, Proceeding of the XVII UISPP World Congress ( 1 - 7 September 2014), Burgos, Spain, Vol. 8, 2014.
} 
(i.e. Croatian Plitvice Lakes National Park and Old City Dubrovnik both on the UNESCO World Heritage List ${ }^{9}$ ). According to the World Heritage Convention ${ }^{10}$ the cultural and natural heritage are increasingly threatened with destruction not only by the traditional causes of decay, but also by changing social and economic conditions. All that motivated authors for this research.

\section{RESEARCH}

The research started with the following hypothesis: 1) by implementing the Balanced Scorecard (BSC) the heritage sites could improve their quality management systems (QMS) and empower the systematic monitoring of realization of their strategic and operational goals; 2) BSC could enable heritage sites for systematic measurement of all their activities; 3) the practical implications could help preventing the situation of endangering, altering, even destroying some valuable sites. A model of strategic management of the heritage sites, presented in the following chapter, resulted after a thorough examination of secondary data, both scientific research (which is scarce) and actual heritage sites, especially endangered ones. Since majority of the observed sites lack strategic management, the risk of being damaged, devastated even destroyed is high. According to the UNESCO List of World Heritage ${ }^{11}$ there $^{2}$ are 53 properties threatened by serious and specific dangers, such as threat of disappearance, rapid urban or tourist development projects, abandonment, outbreak of armed conflict (i.e. Syria, Iraq), serious fires (current situation in Australia), earthquakes or other natural cataclysms. ICOMOS also regularly issues heritage alerts ${ }^{12}$ requesting that the authorities of the endangered sites acknowledge the importance of the location and work to protect and restore it. Regarding the specific attributes of heritage sites that affect tourist satisfaction a well-designed way of presenting the cultural product, including location, internal distribution, walkways, lighting or informative panels, interpretation and the intangibles surrounding the cultural product could stimulate and increase visitors' interest and involvement, leading to perceived value, satisfaction and eventually visitor loyalty, but heritage sites should not be viewed as a product in the traditional sense as they provide intangible and social experiences at the same time ${ }^{13}$.

\section{THE BSC STRATEGIC MODEL}

Balanced Scorecard is methodological foundation which enables management to convert the strategy into quantifiable operative goals, to synchronize the natural, quantitative and qualitative information and to envisage the influence of the executive decisions to the success of the entire organisation. The BSC is widely implemented, in industrial companies, banks, health organizations and government institutions ${ }^{14}$, but it could as well enable tourist destinations and heritage sites to turn their vision and strategy into operational level and

\footnotetext{
${ }^{9}$ World Heritage List, https://whc.unesco.org/en/list/ (15.12.19.)

10 World Heritage Convention Concerning the Protection of the World Cultural and Natural Heritage, https://whc.unesco.org/en/conventiontext/ (15.12.19.)

${ }^{11}$ List of World Heritage in Danger, https://whc.unesco.org/en/danger/ (19.12.19)

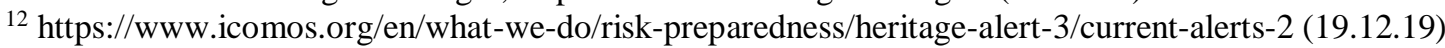

13 Fanny Vong, "Relationships among perception of heritage management, satisfaction and destination cultural image“", Journal of Tourism and Cultural Change, Vol. 11, No. 4, 287-301, 2013.

${ }^{14}$ Violeta Šugar i Tatiana Zanini Gavranić, "BSC and Challenges of the Integrated Quality Management Systems in Higher Education Institutions", Proceedings of the 19 $9^{\text {th }}$ International Symposium on Quality "Quality as a Concept of Development”, Croatian Quality Managers Society, Plitvice Lakes, Zagreb, Croatia, 2018.
} 
measures, organized in four groups or four perspectives (financial, customer, internal processes and learning and growth). Our model proposes strategies that take sustainability into account economic development (marketing and optimization of number of visitors to the heritage sites), society (cooperation with the local community and visitors to ensure true natural values) and environment (biodiversity protection strategy). The selected strategies are observed through four perspectives and within each strategic goals are proposed. Implementation of the BSC as a management tool of the natural and cultural heritage complements the traditional financial performance indicators with other perspectives, namely: customer perspective, internal business process perspective and learning and development perspective (Table 1).

Table 1. BSC model of strategic management of the heritage sites

\begin{tabular}{|l|l|l|l|l|}
\hline \multicolumn{1}{|c|}{$\begin{array}{l}\text { STRATEGIC } \\
\text { GOALS }\end{array}$} & $\begin{array}{l}\text { Biodiversity and } \\
\text { Landscape Protection } \\
\text { Strategy }\end{array}$ & $\begin{array}{l}\text { Collaboration with the } \\
\text { local community }\end{array}$ & $\begin{array}{l}\text { Marketing } \\
\text { Development and } \\
\text { Optimization of NP } \\
\text { Attendance }\end{array}$ & $\begin{array}{l}\text { To provide NP visitors } \\
\text { with true natural } \\
\text { values }\end{array}$ \\
\hline $\begin{array}{l}\text { Financial } \\
\text { perspective }\end{array}$ & Business growth & $\begin{array}{l}\text { Revenue from sales of } \\
\text { products and services and } \\
\text { donations }\end{array}$ & Business profitability & $\begin{array}{l}\text { Sales of educational } \\
\text { materials }\end{array}$ \\
\hline $\begin{array}{l}\text { Customer } \\
\text { perspective }\end{array}$ & $\begin{array}{l}\text { Sustainability and } \\
\text { optimal number of } \\
\text { visitors }\end{array}$ & $\begin{array}{l}\text { Ensure local community } \\
\text { involvement in providing } \\
\text { an indigenous experience }\end{array}$ & $\begin{array}{l}\text { Provide integral nature } \\
\text { protection through } \\
\text { collaboration with other } \\
\text { sectors }\end{array}$ & Loyalty program \\
\hline $\begin{array}{l}\text { Internal } \\
\text { processes }\end{array}$ & $\begin{array}{l}\text { Inventory and evaluate } \\
\text { biological and landscape } \\
\text { diversity and create a } \\
\text { database and monitoring } \\
\text { program }\end{array}$ & $\begin{array}{l}\text { To interpret geo-diversity, } \\
\text { by all available methods } \\
\text { popular science and } \\
\text { educational publications, } \\
\text { "geo-souvenirs", } \\
\text { presentation centres, } \\
\text { museums, etc.) }\end{array}$ & $\begin{array}{l}\text { To know the values of } \\
\text { the landscape of the NP } \\
\text { through the } \\
\text { identification, typology } \\
\text { and scientific- } \\
\text { professional evaluation } \\
\text { of the landscape }\end{array}$ & $\begin{array}{l}\text { Raise the level of } \\
\text { information and } \\
\text { education about the } \\
\text { value and importance of } \\
\text { geo-diversity and } \\
\text { sensitize the public to } \\
\text { protect and preserve } \\
\text { geo-heritage }\end{array}$ \\
\hline
\end{tabular}

Source: Made by the authors.

The financial perspective measures the success of managing natural and cultural heritage by enhancing stakeholders' value, that is, whether the strategies selected contribute to an improved financial position. The strategic objectives proposed for the financial perspective are as follows:

- business growth;

- revenue from the sale of products and services and donations;

- business profitability and

- sales of the educational materials.

The profit is a foundation without which there is no growth and development. The financial perspective reflects the results of past activities but also indicates the need to consider long-term sustainable operations in the value creation process for all stakeholders. Successful management of the natural and cultural heritage can be achieved by realising the goals of all previous perspectives, the common result of which is visible through the financial perspective. 
The customer perspective measures how customer-oriented natural and cultural heritage management strategies and activities affect customer loyalty and greater profitability. The strategic goals proposed for this perspective are the following:

- sustainability and optimal number of visitors;

- ensuring the involvement of the local community in providing an indigenous experience;

- ensuring integrated nature protection through cooperation with other sectors and

- loyalty program.

Customer perspective is the key to managing natural and cultural heritage, because revenue is generated by selling products and services to customers. This perspective allows to set goals and benchmarks for business success in individual customer segments and markets. From a customer perspective it is necessary to evaluate what is valuable and attractive to ensure customer satisfaction and loyalty. Customers have certain expectations about the price and the quality of the product or service purchased, which is why it is important to involve the local community in order to provide indigenous experience. Future generations need to be taken into consideration as well, as informed customers do not want their visit to adversely affect the destination they are visiting.

The internal business process perspective measures how processes of managing natural and cultural heritage should be conducted in order to maximize the efficiency. The strategic objectives considered from the perspective of internal work processes are the following:

- inventorying and evaluation of biological and landscape diversity and developing a database and monitoring program;

- interpreting geo-diversity, using all available methods (i.e. popular science and educational publications, geo-souvenirs, presentation centres, museums, etc.);

- recognizing the values of the heritage site through identification, typology and scientific and professional evaluation of the landscape and

- raising awareness and educating about the values and importance of geodiversity and motivating the public to protect and conserve geo-heritage.

Internal business processes in the management of natural and cultural heritage include all the activities for the protection of biological, landscape and geological diversity, from the global, national, regional and local levels, as well as activities aimed at raising awareness, training and education in the field of landscape conservation.

The learning and (growth) development perspective measures how innovation, education and employee satisfaction can contribute achievement of strategic goals. The proposed objectives of selected strategies, viewed from the perspective of learning and development are as follows:

- strengthened staffing and supervisory services and encouraging activities aimed at raising awareness, training and education in the field of landscape conservation;

- establishing educational-presentation centres and other educational content;

- educating and providing professional training to employees of public institutions and

- employee satisfaction indicator system.

Achievement of strategic objectives should be monitored through the indicators presented in the Table 2. For each operational objective (Table 1) there are four perspectives through which they are monitored.

Table 2: Indicators of achievement of strategic goals 


\begin{tabular}{|c|c|c|c|c|c|}
\hline & $\begin{array}{l}\text { STRATEGIC } \\
\text { GOALS }\end{array}$ & $\begin{array}{l}\text { Biodiversity } \\
\text { and landscape } \\
\text { protection } \\
\text { strategy }\end{array}$ & $\begin{array}{l}\text { Collaboration with } \\
\text { the local } \\
\text { community }\end{array}$ & $\begin{array}{l}\text { Marketing } \\
\text { development and } \\
\text { attendance } \\
\text { optimization of the } \\
\text { heritage sites }\end{array}$ & $\begin{array}{l}\text { To provide visitors } \\
\text { with true natural } \\
\text { values }\end{array}$ \\
\hline \multirow{4}{*}{ 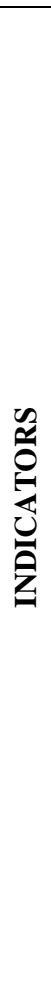 } & $\begin{array}{l}\text { Financial } \\
\text { perspective }\end{array}$ & $\begin{array}{l}\text { Business } \\
\text { profitability }\end{array}$ & $\begin{array}{l}\text { Income from sales of } \\
\text { products and } \\
\text { services and } \\
\text { donations }\end{array}$ & Revenues growth & $\begin{array}{l}\text { Income from sales of } \\
\text { educational programs }\end{array}$ \\
\hline & $\begin{array}{l}\text { Customer } \\
\text { perspective }\end{array}$ & $\begin{array}{l}\text { Customer } \\
\text { satisfaction }\end{array}$ & $\begin{array}{l}\text { Number of visitors } \\
\text { who used the } \\
\text { services and } \\
\text { products created by } \\
\text { the projects in } \\
\text { cooperation with the } \\
\text { local community }\end{array}$ & Number of customers & Customer loyalty \\
\hline & $\begin{array}{l}\text { Internal } \\
\text { processes }\end{array}$ & $\begin{array}{l}\text { Availability of } \\
\text { database and } \\
\text { monitoring } \\
\text { program for } \\
\text { inventorying and } \\
\text { evaluating } \\
\text { biological and } \\
\text { landscape } \\
\text { diversity }\end{array}$ & $\begin{array}{l}\text { Number of popular } \\
\text { science and } \\
\text { educational } \\
\text { publications, "geo- } \\
\text { souvenirs", } \\
\text { presentation centres, } \\
\text { museums, etc.) for } \\
\text { the purpose of } \\
\text { interpretation } \\
\text { geodiversity }\end{array}$ & $\begin{array}{l}\text { Number of } \\
\text { promotional activities } \\
\text { aimed at promoting the } \\
\text { landscape values of the } \\
\text { site through the } \\
\text { identification, } \\
\text { typology and } \\
\text { scientific-professional } \\
\text { evaluation of the } \\
\text { landscape }\end{array}$ & $\begin{array}{l}\text { Number of educations } \\
\text { held regarding the } \\
\text { value and importance } \\
\text { of geo-diversity in } \\
\text { order to sensitize } \\
\text { the public to protect } \\
\text { and preserve geo- } \\
\text { heritage }\end{array}$ \\
\hline & $\begin{array}{l}\text { Learning and } \\
\text { growth }\end{array}$ & $\begin{array}{l}\text { Number of } \\
\text { professional and } \\
\text { supervisory staff }\end{array}$ & $\begin{array}{l}\text { Number of } \\
\text { employees at } \\
\text { activities of } \\
\text { educational and } \\
\text { presentation centres } \\
\text { in the site }\end{array}$ & $\begin{array}{l}\text { Number of employees } \\
\text { who have completed } \\
\text { education and training }\end{array}$ & $\begin{array}{l}\text { Degree of employee } \\
\text { satisfaction }\end{array}$ \\
\hline
\end{tabular}

Source: Made by the authors.

Indicators are proposed in absolute quantities (revenue from sales of products and services and donations), relative (business profitability), natural (number of employees that completed education and training) and qualitative (customer satisfaction), which allows balanced monitoring of the results of implemented strategies. All that in order to determine the achievement of the goals set. Indicators are a measurable basis for comparing and evaluating the performance of past activities, but they can also enable future activities aimed towards selected goals, since it is only possible to manage what is measurable.

\section{CONCLUSION}

Quality, as one of the key drivers of competitiveness of a tourist destination, means the ability of a destination to use its natural, cultural, human, man-made and capital resources efficiently and achieve the ultimate customer/stakeholder satisfaction. Since cultural and natural heritage makes significant component of attraction, as well as of the quality of entire tourist destination, it is of utmost importance to establish the quality management system. One of the proven standards and methodologies is Balanced Scorecard. The BSC enables sustainable management and monitoring of the results of selected strategies through the set goals. The model presented in this paper is a result of the research on heritage sites worldwide, some of them threatened with destruction by variety of reasons, natural and human activity, as well as by changing of social and economic conditions. It is applicable for measuring and 
managing natural and cultural heritage as it complements the traditional financial perspective of the business with three other perspectives: customers, internal business processes and learning and development. The research proved that the implementation of the BSC contributes to the improvement of QMS and enables systematic monitoring of implementation of selected strategic and operational goals. Practical implications could help prevent possible endangering, altering, and even destroying valuable sites. Implementing the BSC enables the organisation (heritage site), both as a whole and each hierarchical level, to be managed in a simple, responsible and transparent way. Detected aberrations in organisational performance ask for corrective measures oriented toward goals achievement. The results of the implemented strategies from the BSC model should be used for benchmarking. Information regarding the performance results compared to the strategic goals in the perspective of the BSC gives evidence about each hierarchical level and the measures for improvement. By implementing the BSC the heritage sites could improve their QMS and empower the systematic monitoring of realization of their strategic and operational goals. BSC could enable heritage sites for systematic measurement of all their activities and help preventing the situation of endangering, altering, even destroying some valuable sites. The research results allow to accept all three hypotheses raised at the beginning of the research

\title{
Sažetak:
}

\author{
STRATEŠKI PRISTUP UPRAVLJANJU \\ KVALITETOM KULTURNE I PRIRODNE BAŠTINE
}

U radu se istražuju i uspoređuju sustavi upravljanja kvalitetom (SUK) područja prirodne i kulturne baštine u Hrvatskoj, Europskoj uniji (EU) i na globalnoj razini. Rezultat je to teorijskog istraživanja provedenog slijedom prethodnih rezultata $i$ istraživanja o integriranim sustavima upravljanja kvalitetom turističkih destinacija, standarda i mjerenja kvalitete. O ovoj se temi relativno malo istražuje i piše, pa je zamjetan nedostatak literature, ali i implementacije kulture kvalitete, što se općenito povezuje s nedostatkom ekonomskih sredstava. Ne postoji suglasje u percepciji potrebe upravljanja kvalitetom kulturne i prirodne baštine, koja se ponekad čak doživljava kao suvišan dodatan teret $i$ trošak. Međutim, prirodna i kulturna baština nedvojbeno predstavljaju turističke atrakcije i kao takve vrijedan su izvor prihoda te je nužno razvijati svijest o potrebi upravljanja kvalitetom i mjerenju kvalitete takvih lokaliteta. Istraživanje se temelji na sljedećoj hipotezi: implementacijom sustava uravnoteženih kartica (Balanced Scorecard, BSC) lokaliteti kulturne i prirodne baštine mogu unaprijediti svoje SUK $i$ kreirati sustavan nadzor nad ostvarenjem svojih strateških i operativnih ciljeva. Praktične implikacije modela strateškog upravljanja, predstavljenog u radu, odnose se na kontrolu i prevenciju mogućih situacija ugrožavanja, negativnih promjena, čak uništavanja vrijednih lokaliteta poput onih u Puli, Dubrovniku ili na Plitvičkim jezerima u Hrvatskoj, odnosno Murujuge u zapadnoj Australiji, indijskog Taj Mahala, lokaliteta u Siriji, Iraku i mnogih drugih.

Ključne riječi: upravljanje kvalitetom, strategija, prirodna i kulturna baština, sustav uravnoteženih kartica.

\section{LITERATURE}

1. Aboriginal Heritage Act 2006 and the Aboriginal Heritage Regulations 2018, https://www.vic.gov.au/aboriginalvictoria/heritage.html

2. Alvarez, D. Maria and Meral Korzay, "Turkey as a heritage tourism destination: The role of knowledge", Journal of Hospitality Marketing and Management, 20, 2011.

3. Carbone, F. "Cultural Heritage Quality Management: Analysis of archaeological heritage managers' perception“, European Journal of Tourism Research 14, 2016. 
4. Grimwade, G. and B. Carter, "Managing Small Heritage Sites with Interpretation and Community Involvement", International Journal of Heritage Studies, Vol. 6, No. 1, 2000.

5. Hausmann, Andrea, "Cultural tourism: Marketing challenges and opportunities for German cultural heritage”, International Journal of Heritage Studies, Vol. 13, No. 2, 2007.

6. ICOMOS Annual Report 2018, https://www.icomos.org/en/resources/publicationall/latesticomos-publications (20.12.2019)

7. Kaplan, R. S. and D. P. Norton, Translating Strategy into Action; The Balanced Scorecard, HBS Press, Boston, 1996.

8. Oosterbeek, L. and F. Pollice, "Cultural Heritage and Local Development. Local communities through heritage awareness and global understanding", Territori della Cultura (18), 2014.

9. Quagliuolo, M., "Quality Management at World Heritage Sites: Challenges", Quality Management of Cultural Heritage: Problems and Best Practices, Proceeding of the XVII UISPP World Congress (1 - 7 September 2014), Burgos, Spain, Vol. 8, 2014.

10. Richards, G., "Tourism attraction systems: Exploring cultural behaviour", Annals of Tourism Research, 29, 2002.

11. Šugar, Violeta, "How to Manage Destinations of Culture; Is Culture a Prime Attraction or Pure Décor?", 4 ${ }^{\text {th }}$ International Conference „Global Challenges for Competitiveness: Business and Government Perspective“, Juraj Dobrila University of Pula, Department of Economics and Tourism „Dr. Mijo Mirković“, Pula, 2007.

12. Šugar, Violeta, EU i odabir modela upravljanja kvalitetom hrvatskih turističkih destinacija, doctoral dissertation, 2008.

13. Šugar, Violeta i Tatiana Zanini, Gavranić, "BSC and Challenges of the Integrated Quality Management Systems in Higher Education Institutions," Proceedings of the $19^{\text {th }}$ International Symposium on Quality "Quality as a Concept of Development", Croatian Quality Managers Society, Plitvice Lakes, Croatia, 2018.

14. Vong, Fanny, "Relationships among perception of heritage management, satisfaction and destination cultural image“, Journal of Tourism and Cultural Change, Vol. 11, No. 4, 2013.

15. World Heritage Convention Concerning the Protection of the World Cultural and Natural Heritage, https://whc.unesco.org/en/conventiontext/ (15.12.19.)

16. World Heritage List, https://whc.unesco.org/en/list/ (15.12.19.)

17. World Tourism Organization, "UNWTO Guidelines for Institutional Strengthening of Destination Management Organizations (DMOs) - Preparing DMOs for new challenges“, DOI: https://doi.org/10.18111/9789284420841, Madrid, 2019. 